Rev. Latinoam. Psicopat. Fund., São Paulo, v. 10, n. 4, p. 692-695, dez.2007

\title{
Tratado sobre patologia e terapêutica das doenças mentais*
}

Wilhelm G riesinger

\section{Sobre o substrato das enfermidades mentais e o método que convém seguir em seu estudo}

$\mathbf{1}^{\mathbf{0}}$ A obra que hoje publicamos tem como finalidade estudar as enfermidades mentais, aprender a reconhecê-las e a curá-las. A loucura, estado anormal da inteligência e da vontade, é apenas um sintoma; somente estudando essas enfermidades mentais sob um ponto de vista sintomatológico poderemos chegar a dividi-las em um certo número de grupos principais, cuja existência não poderia justificar-se de nenhum outro modo. O primeiro passo para chegar a entender estes sintomas consiste em localizá-los. A que órgão pertencem os fenômenos da loucura? Qual deve ser o órgão repetida e principalmente enfermo nos casos de loucura? A resposta a estas perguntas constitui a condição primeira de toda a psiquiatria.

Se os fatos psicológicos e patológicos nos indicam que este órgão não pode ser outro que o cérebro, deduz-se que, antes que nada, em toda enfermidade mental devemos ver sempre uma afecção do cérebro.

* Traduzido pelo prof. dr. Mário Eduardo Costa Pereira, do Laboratório de Psicopatologia Fundamental / Unicamp, a partir de: Rev Psiquiatria Fac Med Barna, v. 28, n. 5, p. 308-10, 2001. Griesinger, W. Traité sur la pathologie et la thérapeutique des maladies mentales. Paris: A. Delahaye Libraire-Éditeur, 1873. 
$\mathbf{2}^{\mathbf{0}}$ A psicologia considera a vida psíquica uma forma vital particular do organismo; nos atos psíquicos, vê as funções de um órgão determinado, assim como tenta deduzi-las a partir da estrutura desse órgão. Na verdade, algumas experiências conhecidas demonstram que, se as faculdades psíquicas, no sentido mais amplo do termo, vão ligadas a todo o sistema nervoso, o centro da inteligência e das faculdades afetivas reside no cérebro, e mesmo apenas em algumas partes desse órgão. Certamente, os diferentes estados de todo o sistema nervoso, transmitidos imediatamente ao cérebro, aportam alguns elementos capazes de manter e excitar as faculdades mentais (todo o sistema nervoso periférico pode ser o ponto de partida de impressões que modificarão nossos instintos e nossos afetos, que nos dão concepções mais ou menos claras ou obscuras). Mas o cérebro é o único que capta e percebe estas impressões, nele é onde se traduz a influência que exercem estas impressões sobre toda uma série de movimentos determinados e coordenados (sobre os atos); em duas palavras, é no cérebro onde nascem a percepção e o esforço que estas impressões determinam...

Observamos que, na série animal, as faculdades psíquicas são muito mais numerosas e mais variadas, que alcançam um aperfeiçoamento mais completo, que o cérebro apresenta um volume mais considerável, uma organização mais complexa e que a substância própria dos hemisférios em particular é mais volumosa. Por outro lado, observamos que no ser humano um defeito considerável no desenvolvimento do cérebro vai ligado a uma debilitação dos atos psíquicos elevados, da inteligência e da vontade (como freqüentemente podemos observar nos casos de idiotismo). Além disso, a experiência nos ensina que, em todos os seres humanos, as faculdades mentais experimentam modificações essenciais segundo o desenvolvimento e os câmbios que sofre o cérebro nas diferentes idades da vida. Nessas modificações temporais, nesse desenvolvimento progressivo através do qual o cérebro alcança progressivamente seu apogeu, para em seguida sofrer um retrocesso, a atividade intelectual do cérebro segue o mesmo ritmo que todas as funções orgânicas e se revela submetido, tal como estas, à lei do desenvolvimento do organismo...

$3^{\mathbf{0}}$ Tal como os fatos fisiológicos, os fatos patológicos revelam que unicamente o cérebro pode ser o centro das faculdades mentais, sejam normais ou mórbidas, e que a integridade do funcionamento psíquico depende da integridade desse órgão, ambas podendo ver-se alteradas por um fato patológico que tenha seu substrato em algum órgão mais ou menos próximo ao cérebro. Os sintomas constantes e essenciais das enfermidades cerebrais, sejam produzidas por causas internas ou por uma lesão externa, consistem igualmente, além das anomalias da sensibilidade e do movimento, quando a enfermidade é grave, em alterações intelectuais (exaltação ou perda da inteligência, perda da consciência, 
delírio etc.). Os casos menos freqüentes, nos que, na presença de uma desorganização grave do cérebro ou de uma perda de substância desse órgão, não se observa nenhuma alteração mental, não podem retirar valor aos resultados obtidos na observação diária...

Sem dúvida, além do transtorno das faculdades intelectuais e afetivas, na maioria das enfermidades mentais ainda se observam anomalias importantes de outras funções, que evidentemente também são próprias ao cérebro. Em primeira linha encontram-se as alucinações, anomalias da função central dos sentidos, que em grande parte são percebidas como impressões periféricas, mas cuja produção deve ser obrigatoriamente transmitida ao cérebro, como assim o demonstram os fatos das alucinações persistentes da visão, em indivíduos que padecem de cegueira total com atrofia dos nervos ópticos (Esquirol)...

$4^{\mathbf{0}}$ Apesar de os fatos nos levarem forçosamente a transmitir a inteligência e a vontade ao cérebro, não devemos prejulgar nada sobre a relação existente entre os atos psíquicos e o cérebro, entre a alma e a matéria. Desde um ponto de vista empírico, antes de tudo devemos ratificar o fato da unidade da alma e do corpo e deixar que os métodos concebidos a priori estudem uma alma imaterial, a alma independente do corpo, e contentar-se com considerações abstratas sobre sua imaterialidade e sua unidade em oposição à multiplicidade da matéria etc. Como pode ser que um fenômeno material, físico, que tem lugar nas fibras nervosas ou nas células ganglionares, possa converter-se em uma idéia, em um ato da consciência?, fato totalmente incompreensível. Eu ainda iria mais longe: nem sequer sabemos como colocar uma pergunta relativa à existência e à natureza dos intermediários que unem estas duas ordens de fatos. Nesse sentido, tudo permanece relegado ainda ao campo da possibilidade...

Nem o materialismo, que pretende explicar todos os atos físicos através da matéria, nem o espiritualismo, que pretende explicar a matéria através da alma, nos dão uma idéia exata daquilo que ocorre na alma. Além disso, se chegarmos a saber tudo o que se produz no cérebro quando este entra em ação, a penetrar em todos os secretos da química, da eletricidade etc., de que nos serviria tudo isto?... Como podem esses fatos transformar-se em fatos espirituais? Este problema permanecerá insolúvel para o homem até o fim dos tempos e pessoalmente creio que, a não ser que um anjo desça dos céus e nos resolva este mistério, nossa alma não será capaz de compreendê-lo por si própria...

$5^{\mathbf{0}}$ De acordo com as premissas apresentadas até agora, a questão que tanto e durante tanto tempo tem tratado a antiga psiquiatria alemã, isto é, se a enfermidade afeta realmente e do mesmo modo a alma no caso da loucura e as anomalias da inteligência e da vontade, encontrará sua solução simples e afirmativa. Mas, certamente, não poderemos falar de enfermidades da alma em si mesmas; tal como o que ocorre com as patologias exatas, que podem nos falar 
das enfermidades dos fenômenos vitais e das funções, mas unicamente das enfermidades cerebrais que implicam uma alteração nos atos da inteligência e da vontade.

$\mathbf{6}^{\circ}$ Mas se todos os casos de loucura dependem de uma afecção cerebral, nem todas as enfermidades do cérebro devem ser englobadas nas enfermidades mentais por esta mesma razão. Qual é então o tipo de afecção cerebral à qual nos defrontamos no caso da loucura? Desde um ponto de vista anatômico, tratamse das enfermidades mais diversas, cujos conjuntos de sintomas levam o nome de loucura...

Em grande parte, a patologia cerebral se encontra, mesmo hoje em dia, no ponto onde caiu a patologia dos órgãos torácicos, antes de Laennec. Em lugar de tomar como ponto de partida em geral algumas alterações estruturais dos órgãos e poder deduzir de maneira precisa a produção de sintomas das alterações produzidas nos tecidos, a patologia cerebral vai em geral relacionada com os conjuntos de sintomas cujo centro conhece apenas aproximadamente e cujo mecanismo de produção lhe escapa por completo...

$7^{\circ}$ Dado que a loucura não é mais que um complexo sintomático de diferentes estados anormais do cérebro, poderíamos perguntar se seria legítimo, de maneira geral, levar a cabo um estudo específico das enfermidades mentais separado das outras afecções do cérebro ou, antes, a psiquiatria não deveria entrar de nenhum modo, nem mesmo formalmente, na patologia cerebral. Ainda que isto não me pareça impossível em um futuro mais ou menos longínquo, qualquer tentativa que tenha como finalidade mesclar, no que se refere ao presente, estas duas ordens de enfermidades seria, não obstante, prematura e absolutamente impraticável...

$\mathbf{8}^{\mathbf{0}}$ Tendo em conta que a loucura é uma enfermidade e, ainda, uma enfermidade do cérebro, disso se deduz que esta não pode ser estudada adequadamente senão desde um ponto de vista médico. A anatomia, a fisiologia e a patologia do sistema nervoso e toda a patologia e a terapêutica específicas entendidas em conjunto representam os conhecimentos prévios que mais necessita o médico alienista. Todos os estudos extramédicos sobre a loucura, e em particular todos os que têm sido realizados por poetas e moralistas, têm muito pouco valor, desde o ponto de vista do conhecimento dessa afecção.

\section{WiLhelm Griesinger (1817-1868)}

Psiquiatra alemão; catedrático da Universidade de Frankfurt; autor do Tratado sobre patologia e terapêutica das doenças mentais (1845); primeiro titular da clínica psiquiátrica do Hospital Burghölzli, em 1860. 